\title{
Kemampuan Alat Deteksi Dini Risiko Malnutrisi Menurut American Society for Parenteral and Enteral Nutrition pada Anak 6-60 Bulan oleh Orang Tua
}

\author{
Syarifah Prita Yulianty Permatasari, Dida A. Gurnida, Alex Chairulfatah \\ Departemen Ilmu Kesehatan Anak Fakultas Kedokteran Universitas Padjadjaran RSUP Dr. Hasan Sadikin, Bandung
}

\begin{abstract}
Latar belakang. Status gizi merupakan faktor penting dalam perkembangan dan pertumbuhan anak terutama usia 6-60 bulan yang rentan terjadinya malnutrisi. Deteksi risiko malnutrisi merupakan tugas semua pihak termasuk orang tua, Selama ini dilakukan oleh dokter dan ahli gizi, tidak ada alat skrining yang dapat digunakan orang tua. American Society for Parenteral and Enteral Nutrition (ASPEN) mengeluarkan panduan mendeteksi risiko malnutrisi pada anak oleh orang tua.

Tujuan. Menilai kemampuan alat deteksi dini risiko malnutrisi menurut ASPEN oleh orang tua.

Metode Penelitian uji diagnostik ini dilakukan dari September hingga Oktober 2018 di 3 Posyandu di wilayah kerja Puskesmas Sukajadi, Bandung, Indonesia dan melibatkan 75 pasang orang tua dan anak berusia 6-60 bulan. Pemilihan tempat dan subjek penelitian dilakukan secara purposive cluster sampling. Orang tua melakukan penilaian mengenai risiko pada anaknya menurut ASPEN, status gizi anak dinilai berdasarkan perbandingan berat badan (BB) dengan tinggi badan (TB). Anak dinilai memiliki risiko malnutrisi menurut metode ASPEN bila ada minimal salah satu jawaban 'iya' dari 9 kriteria pertanyaan, anak dinilai mempunyai risiko malnutrisi menurut peneliti bila ditemukan pemeriksaan antropometri $Z$-Score $<-1 \mathrm{SD}$. Uji diagnostik terhadap metode ASPEN dilakukan dengan baku emas BB/TB.

Hasil. Uji diagnostik menunjukkan sensitivitas, spesifisitas, nilai prediksi positif dan negatif sebesar masing masing 78,95 \%, 28,57 $\%, 27,27$ dan 80\%. Dengan rasio kemungkinan positif sebesar 1,1053 dan rasio kemungkinan negatif sebesar 0,7368.

Kesimpulan. Malnutrisi tidak jarang ditemukan, sehingga walaupun memiliki spesifitas yang tidak begitu tinggi metode ASPEN berguna bagi orang tua dalam mengawasi status gizi anak. Sari Pediatri 2019;21(1):50-6
\end{abstract}

Kata kunci: deteksi dini, risko malnutrisi, status gizi, alat skrining

\section{Ability of the Early Detection Tool at Risk of Malnutrition for 6-60 Months Old Children of the Parents According to the American Society for Parenteral and Enteral Nutrition}

\author{
Syarifah Prita Yulianty Permatasari, Dida A. Gurnida, Alex Chairulfatah
}

Background. Nutritional status is an important factor in children development and growth, especially at age 6-60 months that are susceptible to the occurrence of malnutrition. Detection of the risk of malnutrition is the duty of all parties including the parents. In the previous time, screening of risk or malnutrition has just done by doctors and nutritionists, there is no screening tool that can be used by parents. The American Society for Parenteral and Enteral Nutrition (ASPEN) issued a guide in the dangers of malnutrition on children by the parents.

Objective. To assess the ability of the screening tool for risk of malnutrition for children of the parents according to ASPEN method. Method. This diagnostic study was conducted from September to Oktober 2018 at 3 Posyandu in the work area of Sukajadi health center, Bandung, Indonesia and involved 75 parents and 6-60 months old children. The choice of place and subject of the study was conducted by purposive cluster sampling. The parents assessment of the risks to their children according to ASPEN, the nutritional status of children was assessed based on the ratio of body weight and height. Children were considered to risk of malnutrition according to ASPEN method if they have at least one from nine criteria, children were considered to have a risk of malnutrition according the researcher if found anthropometric examination Z-Score $<-1$ SD.

Results. This diagnostic study showed sensitivity, specificity, positive and negative predictive value of 78.95\%, 28.57\%, 27.27 and $80 \%$ respectively, where a positive likelihood ratio was 1.1053 and a negative likelihood ratio was 0.7368 .

Conclusion. Malnutrition was not uncommon, so even though it had a very high specificity the ASPEN method is useful for parents in monitoring the nutritional status of children. Sari Pediatri 2019;21(1):50-6

Keywords: early detection, nutritional status, risk of malnutrition, screening tool

Alamat korespondensi: Dida A Gurnida. Departemen Ilmu Kesehatan Anak FK UNPAD/ RS Dr Hasan Sadikin Bandung, Gedung Kenanga Lantai 3, Jl. Pasteur 38, Bandung, Indonesia. Telepon/ Fax: (022) 2035957/ 2034426, E-mail: didaag@yahoo.com 
Syarifah P. Y. Permatasari dkk: Kemampuan alat deteksi dini risiko malnutrisi menurut ASPEN pada anak 6-60 bulan

S tatus gizi merupakan faktor penting dalam menjamin perkembangan dan pertumbuhan seorang anak yang optimal. Pada periode tumbuh kembang, terutama usia 6-60 bulan, anak rentan terhadap kekurangan asupan gizi. Hal tersebut mengakibatkan anak jatuh ke dalam kondisi malnutrisi dengan berbagai gejala dan penyulitnya.

Malnutrisi merupakan salah satu masalah kesehatan utama yang menjadi perhatian internasional, khususnya di negara berkembang. World Health Organization (WHO) menyebutkan sekitar 50\% dari 10 juta kematian anak di bawah usia 5 tahun di negara berkembang, berkaitan dengan defisiensi energi dan protein. ${ }^{1-5}$ Berdasarkan Riset Kesehatan Dasar (RISKESDAS) 2013 prevalensi malnutrisi pada anak balita di Indonesia cukup tinggi, yaitu sebesar 19,6\% yang meningkat dari 18,4\% tahun 2007 dan 17,9\% pada tahun $2010 .^{1}$

Penilaian status gizi berkala merupakan upaya dalam deteksi dini malnutrisi sehingga dapat dilakukan tindakan yang semestinya. Penilaian status gizi anak sering sekali hanya dilakukan oleh tenaga kesehatan pada saat anak dibawa berobat karena penyakit lain. Seyogyanya, penilaian gizi dilakukan berkala oleh orang tua karena penilaian status gizi oleh tenaga kesehatan hanya dilakukan pada saat anak sakit. Menentukan status gizi seorang anak diperlukan pemeriksaan lengkap meliputi anamnesis, pemeriksaan fisis lengkap, pengukuran antropometri, dan laboratorium yang hanya bisa dilakukan oleh tenaga kesehatan dan tidak bisa dilakukan oleh orang tua. ${ }^{6-8}$ Sampai saat ini hanya sedikit alat skrining yang dapat digunakan orang tua dalam menilai status gizi anaknya. ${ }^{2,9-11}$

American Society for Parenteral and Enteral Nutrition (ASPEN) dalam Malnutrition Awarness Week mengeluarkan panduan untuk mendeteksi risiko malnutrisi pada anak oleh orang tua. Panduan tersebut lebih praktis, waktu lebih singkat serta mudah dipahami. ${ }^{12}$ Dengan deteksi dini risiko malnutrisi oleh orang tua, diharapkan orang tua akan segera membawa anak berobat untuk mendapat tindakan yang seharusnya.

Penelitian bertujuan menilai kemampuan metode ASPEN dalam deteksi dini risiko malnutrisi pada anak 6-60 bulan oleh orang tua. Penelitian ini diharapkan dapat digunakan sebagai salah satu bentuk kerjasama antara orang tua dan dokter dalam mendeteksi kemungkinan malnutrisi pada anak sehingga dapat dilakukan intervensi segera.

\section{Metode}

Penelitian dilakukan pada September hingga Oktober 2018 pada 3 Posyandu di wilayah kerja Puskesmas Sukajadi, Bandung yang telah disetujui oleh komite etik Fakultas Kedokteran Universitas Padjadjaran. Penelitian ini menggunakan metode analitik dengan pendekatan potong lintang.

Perhitungan statistik dari kedua penilaian dilakukan dengan analisis uji diagnostik sehingga didapatkan nilai sensitifitas, spesifisitas, nilai prediksi positif, nilai prediksi negatif, rasio kemungkinan positif, dan rasio kemungkinan negatif. Pemilihan sampel dilakukan dengan purposive cluster sampling, yaitu dengan memilih Puskesmas Sukajadi yang merupakan Puskesmas mitra Fakultas Kedokteran Universitas Padjadjaran. Selanjutnya dilanjutkan ditentukantiga Posyandu dengan jumlah sampel 75 pasangan orang tua dan anak.

Kriteria inklusi penelitian adalah pasangan orang tua yang memiliki anak laki-laki atau perempuan dan berusia 6-60 bulan. Kriteria eksklusi penelitian ini adalah orang tua tidak dapat menyelesaikan pengisian kuesioner secara lengkap atau anak yang mengalami cacat fisik dan atau kelainan kongenital. Kuesioner yang dipakai adalah terjemahan kuesioner menurut ASPEN yang telah melewati uji adaptasi kultural, validitas dan reliabiltas kuesioner pada 30 subjek.

Setelah mengisi lembar persetujuan, orang tua diminta untuk mengisi kusioner ASPEN yang terdiri dari 9 pertanyaan mengenai apakah anak mengalami penurunan berat badan (BB), peningkatan $B B$ yang lambat, atau memiliki BB yang kurang; anak tidak bertambah tinggi; ukuran pakaian anak tidak bertambah; jumlah makan lebih sedikit dari biasanya; tidak berselera makan atau tidak nafsu makan; menggunakan selang makan atau mekan makanan khusus; anak tidak mau makan karena ada masalah diperut; anak kurang aktif dan jarang bermain dari biasanya; dan lebih tidur dari biasanya. Subjek yang menjawab minimal satu jawaban "iya" dari sembilan pertanyaan dalam kuesioner tersebut dimasukkan ke dalam subjek yang berisiko mengalami malnutrisi. Sebagai baku emas untuk menilai kinerja metode ASPEN adalah status antropometri BB menurut panjang badan $(\mathrm{PB})$ atau tinggi badan $(\mathrm{TB})(\mathrm{BB} / \mathrm{PB}$ atau $\mathrm{BB} / \mathrm{TB}$ ) berdasarkan $\mathrm{WHO}$ dengan nilai $Z$-score $<-1$ SD dinilai sebagai anak risiko malnutrisi yang akan dibandingkan dengan penilaian orang tua menurut metode ASPEN. Statistik yang digunakan adalah uji 
keselarasan Kappa antara kriteria $\mathrm{BB} / \mathrm{PB}$ dengan Z-score $<-1 \mathrm{SD}$ sebagai gold standar risiko malnutrisi dengan deteksi dini risiko malnutrisi menurut ASPEN. Bila ditemukan nilai uji keselarasan yang positif selanjutnya akan dilakukan uji diagnostik.

\section{Hasil}

Selama periode penelitian terdapat 75 pasang subjek penelitian yang memenuhi kriteria inklusi dan eksklusi.
Karakteristik subjek peneitian anak mencakup jenis kelamin, usia, BB, TB, usia kehamilan, BB lahir, PB lahir, dan pekerjaan dan pendidikan orang tua yang tertera pada Tabel 1 .

Subjek penelitian terdiri dari $43(57,3 \%)$ laki-laki dan $32(42,7 \%)$ perempuan dengan usia rata-rata 29 bulan (rentang 7-59). Berat badan lahir rentang 2,14,9 kg dengan riwayat kehamilan 96\% cukup bulan dan 4\% kurang bulan. Pengukuran BB rentang 7-18,7 $\mathrm{kg}$ dan PB atau TB rentang $64-106 \mathrm{~cm}$. Pendidikan ayah dan ibu paling banyak lulusan SMA / SMK dan

Tabel 1. Karakteristik subjek penelitian

\begin{tabular}{|c|c|c|}
\hline Variabel karakteristik balita & Ukuran statistik & $(\%)$ \\
\hline \multicolumn{3}{|l|}{ Jenis kelamin (n) } \\
\hline Laki-laki & 43 & 57,3 \\
\hline Perempuan & 32 & 42,7 \\
\hline Usia (bulan), rerata, rentang & $29(7-59)$ & \\
\hline \multicolumn{3}{|l|}{ Usia kehamilan } \\
\hline Cukup bulan & 72 & 96 \\
\hline Kurang bulan & 3 & 4 \\
\hline $\mathrm{BB}(\mathrm{kg})$, rentang & $7,0-18,7$ & \\
\hline $\mathrm{PB} / \mathrm{TB}(\mathrm{cm})$, rentang & $64,0-106,0$ & \\
\hline BB lahir (kg), rentang & $2,1-4,9$ & \\
\hline PB Lahir $(\mathrm{cm})$, rentang & $37-53$ & \\
\hline \multicolumn{3}{|l|}{$\mathrm{BB} / \mathrm{TB}$ atau $\mathrm{BB} / \mathrm{PB}$} \\
\hline$Z$-score $<-1 \mathrm{SD}$ & 19 & 25,3 \\
\hline$Z$-score $\geq-1 \mathrm{SD}$ & 56 & 74,7 \\
\hline \multicolumn{3}{|c|}{ Karakteristik orang tua (pekerjaan) } \\
\hline Karyawan swasta & 31 & 41,3 \\
\hline PNS & 3 & 4,0 \\
\hline Wiraswasta & 20 & 26,7 \\
\hline Buruh & 14 & 18,7 \\
\hline IRT & 7 & 9,3 \\
\hline Pendidikan Ayah & 7 & 9,3 \\
\hline SD & 9 & 12,0 \\
\hline SMP & 45 & 60,0 \\
\hline SMA/SMK & 14 & 18,7 \\
\hline \multicolumn{3}{|l|}{ Akademi/PT } \\
\hline \multicolumn{3}{|l|}{ Pendidikan Ibu } \\
\hline SD & 6 & 8,0 \\
\hline SMP & 16 & 21,3 \\
\hline SMA/SMK & 41 & 54,7 \\
\hline Akademi/PT & 11 & 14,7 \\
\hline Tidak diketahui & 1 & 1,3 \\
\hline
\end{tabular}


Syarifah P. Y. Permatasari dkk: Kemampuan alat deteksi dini risiko malnutrisi menurut ASPEN pada anak 6-60 bulan

Tabel 2 Kuesioner tanda dan gejala deteksi dini risiko malnutrisi menurut ASPEN

\begin{tabular}{lc}
\hline Pertanyaan & Jawaban ya (\%) \\
\hline Apakah saat ini anak Anda mengalami penurunan berat badan, peningkatan berat badan yang & $24(32,0)$ \\
lambat atau memiliki berat badan kurang? & \\
Apakah anak Anda tidak bertambah tinggi? & $12(16,0)$ \\
Apakah ukuran pakaian anak Anda tidak bertambah/ tidak menjadi sempit? & $8(10,7)$ \\
Apakah anak Anda jumlah makan lebih sedikit dari biasanya? & $19(25,3)$ \\
Apakah anak Anda tidak berselera atau tidak nafsu makan? & $32(42,7)$ \\
Apakah anak Anda menggunakan selang makan atau makan makanan khusus? & $3(4,0)$ \\
Apakah anak Anda tidak mau makan karena ada masalah diperut? & $5(6,7)$ \\
Apakah anak anda kurang aktif dan jarang bermain dari biasanya? & $6(8,0)$ \\
Apakah anak Anda lebih banyak tidur dari biasanya? & $9(12,0)$ \\
\hline Gabungan (minimal punya satu masalah) & $55(73,3)$ \\
\hline
\end{tabular}

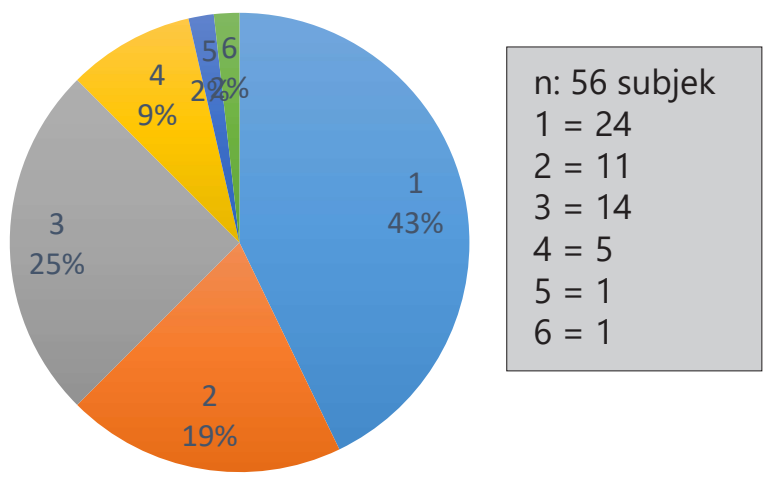

$1 \square 2 \square 3 \square 4 \square 5 \square 6$

Gambar 1. Total jawaban “iya” pada setiap subjek yang berisiko malnutrisi

pekerjaan orang tua yaitu sebanyak 31 (41\%) adalah karyawan swasta. Berdasarkan hasil pemeriksaan antropometri $\mathrm{BB} / \mathrm{PB}<-1 \mathrm{SD}$ ditemukan sebanyak 19 $(25,3 \%)$ balita berisiko malnutrisi.

Ditemukan sebanyak $56(74,7 \%)$ orang tua menyatakan bahwa anaknya memiliki risiko malnutrisi yang tertera pada Tabel 2. Gambaran anak yang paling banyak dijumpai adalah anak tidak berselera atau tidak mempunyai nafsu makan (42,7\%), dan anak mengalami penurunan berat badan atau memiliki berat badan kurang sebanyak 32,0\%. Sedangkan jawaban dari tanda dan gejala yang paling sedikit adalah anak menggunakan selang makan atau makan makanan khusus (4\%).

Orang tua yang menyatakan anaknya mempunyai risiko malnutrisi melalui jawaban positif dari 1 pertanyaan ditemukan pada 24 (32\%), sedangkan
Tabel 3. Uji Keselarasan Kappa antara kriteria BB/TB

$Z$-score $<-1 \mathrm{SD}$ sebagai standar emas

\begin{tabular}{lcc}
\hline \multirow{2}{*}{ Kappa } & \multicolumn{2}{c}{ CI 95\% } \\
\cline { 2 - 3 } & Lower & Upper \\
\hline 0,0462 & $-0,0228$ & 0,1153 \\
\hline
\end{tabular}

yang mempunyai risiko malnutris melalui 2, 3,4,5, dan 6 pertanyaan ditemukan masing-masing pada 11 $(14,6 \%), 14(18,6 \%), 1(1,3 \%)$ dan $1(1,3 \%)$ subjek penelitan seperti terlihat pada Gambar 1.

Nilai kofisien ukuran keselarasan Kappa dari metode ASPEN dengan pemeriksaan antropometri $\mathrm{BB} / \mathrm{TB}$ adalah 0,0462 nilai menunjukkan bahwa hasil deteksi dini risiko malnutrisi menurut ASPEN masih selaras dengan pengukuran $\mathrm{BB} / \mathrm{TB}$ walaupun tidak begitu erat.

Dari 75 subjek dari pasangan orang tua dan balita, terdapat 19 balita $(25,3 \%)$ yang berisiko malnutrisi menurut pengukuran antropometri, terdiri dari 4 balita $(5,3 \%)$ yang tidak memiliki jawaban positif dan 15 balita (20\%) dengan minimal 1 jawaban positif dari pertanyaan yang terdapat pada kuesioner yang tertera pada Tabel 4. Penghitungan sensitifitas, spesifisitas, NPP, NPN, berturut-turut 78,95\%, 28,57\%, 27,27 dan 80\%.

Rasio kemungkinan positif atau (+)LR mempunyai nilai yang lebih besar 1,1053 dibandingkan rasio kemugkinan negative atau (-)LR yang tertera pada Tabel 5

\section{Pembahasan}

Anak didefinisikan sebagai seseorang yang berusia kurang dari 18 tahun, termasuk anak yang masih 
Syarifah P. Y. Permatasari dkk: Kemampuan alat deteksi dini risiko malnutrisi menurut ASPEN pada anak 6-60 bulan

Tabel 4. Pengukuran antropometri BB/PB Z-Score menurut hasil penelitian ASPEN

\begin{tabular}{ccccc}
\hline & & \multicolumn{2}{c}{ Antropometri BB/PB $(Z$-score $)$} & \multirow{2}{*}{ Total } \\
\cline { 3 - 4 } & & $(<-1$ SD $)$ & $\geq-1$ SD & \\
\hline \multirow{3}{*}{ ASPEN } & Risiko malnutrisi $(+)$ & 15 & 40 & 55 \\
\hline Total & Risiko malnutrisi $(-)$ & 4 & 16 & 20 \\
\hline
\end{tabular}

Tabel 5. Sensitivitas, spesifisitas, nilai prediksi positif (NPP), nilai prediksi negative (NPN) dan likelihood ratio positif dan likelihood ratio positif deteksi dini risiko malnutrisi menurut ASPEN

\begin{tabular}{cccccc}
\hline $\begin{array}{c}\text { Sensitivitas } \\
\text { (IK95\%) }\end{array}$ & Spesifisitas & $(+)$ PV & $(-)$ PV (IK95\%) & (+) LR (CI95\%) & $(-)$ LR (CI95\%) \\
\hline $0,7895(0,6972-$ & $0,2857(0,1835-$ & $0,2727(0,1719-$ & $0,8(0,7095-$ & $1,1053(0,8853-$ & $0,7368(0,5169-$ \\
$0,8817)$ & $0,388)$ & $0,3735)$ & $0,8905)$ & $1,3252)$ & $0,9568)$ \\
\hline
\end{tabular}

Keterangan: (+) PV: Positive predictive value/ NPP ; (-)PV: Negative predictive value / NPN; (+) LR: Positive likelihood ratio/rasio kemungkinan positif; (-) LR: Negative likehood ratio/ rasio kemungkinan negative CI: Confidens Interval

dalam kandungan. ${ }^{13,14}$ Status gizi merupakan faktor penting dalam menjamin kesehatan perkembangan dan pertumbuhan seorang anak. Pada periode tumbuh kembang, terutama usia 6-60 bulan, anak rentan terhadap kekurangan asupan gizi sehingga mengakibatkan anak mudah jatuh pada kondisi malnutrisi. ${ }^{1-4,15,16}$

Di negara berkembang, angka kejadian malnutrisi cukup tinggi sehingga berdampak negatif bagi kualitas kehidupan pribadi dan kehidupan berbangsa. Di Indonesia, angka kejadian malnutrisi menurut hasil RISKESDAS 2013 masih cukup tinggi, yaitu 19,6 \%. Diperlukan upaya untuk menurunkan kejadian malnutrisi di masyarakat, salah satunya adalah deteksi dini dari anak mempunyai risiko untuk mengalami atau menderita malnutrisi. Selama ini, upaya ini merupakan tanggung jawab petugas kesehatan semata, padahal orang tua dan masyrakat sangat berperan penting dalam menilai status gizi anak. Hal ini antara lain disebabkan tenaga kesehatan yang terbatas dan anak dibawa ke dokter sering sekali atas keluhan lain, seperti batuk, pilek dan demam. Kendala dalam penilaian status gizi anak oleh orang tua adalah tidak adannya suatu alat atau cra yang mudah dilakukan orang tua.

Penelitian-penelitian sebelumnya seperti European Society for Clinical Nutrition and Metabolism (ESPEN) mengeluarkan pedoman berupa Malnutrition Universal Screening Tool (MUST), Nutritional Risk Screening (NRS 2002) dan initial Screening in Mini Nutritional Assessment (MNA), Screening Tool for Risk of Nutritional Status and Growth (STRONGkids), Subjective Global Nutritional Assessment in Children (SGNA), Simple Pediatric Nutritional
Risk Score of malnutrition, Screening Tool for the Assessment of malnutrition in Pediatrics (STAMP) dan Nutrition Screeninng Tool for every Presschooler (NutriSTEP) menyampaikan skrining risiko malnutrisi pada anak jika pasien dirawat di rumah sakit dan dilakukan oleh dokter nutrisi dan ahli gizi. Belum ada alat skrining yang dapat digunakan kepada orang tua dalam mengetahui risiko masalah nutrisi pada anaknya. ${ }^{2,9-11,17}$

Antropometri adalah suatu metode paling mudah, bersifat universal, murah, dan noninvasive. Pengukuran ini dilakukan berulang secara berkala untuk mengkaji pertumbuhan jangka pendek, jangka panjang, dan status nutrisi. ${ }^{5-7,18}$ Penggunaan $Z$-score sebagai baku emas dikenal luas sebagai sistem terbaik dalam analisis dan presentasi data antropometri. ${ }^{4,5,18}$ Perbandingan relatif BB/PB memberikan berbagai informasi tentang pertumbuhan dan status gizi seorang anak. Indeks BB/PB akurat dalam menetapkan dan mengklasifikasikan status gizi pada seorang anak serta indeks independen terhadap usia. $3-5,18$

American Society for Parenteral and Enteral Nutrition dalam Malnutrition Awarness Week mengeluarkan panduan untuk mendeteksi risiko malnutrisi pada anak oleh orang tua, sehingga deteksi dini risiko malnutrisi pada anak lebih mudah dikenali. ${ }^{12}$ Dengan demikian diharapkan orang tua dapat membawa anaknya ke fasilitas kesehatan untuk mendapat pengobatan dari risiko malnutrisi.

Dokter atau pekerja di institusi kesehatan sebagai unit terkecil dalam masyarakat diharapkan dapat secara mandiri mengenali permasalahan gizi yang terjadi di lingkungannya secara dini sehingga bisa segera dilakukan upaya penanganan secara cepat dan tepat. ${ }^{3,7,19}$ Deteksi dini risiko malnutrisi 
Syarifah P. Y. Permatasari dkk: Kemampuan alat deteksi dini risiko malnutrisi menurut ASPEN pada anak 6-60 bulan

dan tata laksana yang tepat waktu dapat terbukti mengurangi komplikasi malnutrisi. Deteksi dini dimasyarakat terutama di dalam keluarga sangat penting untuk menurunkan angka kejadian malnutrisi. $6,15,16,19$

Penelitian ini menunjukkan bahwa secara antropometri $19(25,3 \%)$ dari 75 subjek penelitian memiliki risiko untuk terjadinya malnutrisi. Hasil RISKEDAS 2013 terjadi peningkatan 19,6\% dari 18,4\% tahun 2007 dan 17,9\% pada tahun 2010. ${ }^{1}$ Menurut uji keselarasan Kappa, ditemukan koefisien sebesar 0,0462. walaupun nilainya kecil berarti terdapat keselarasan searah antara metode antropometri BB/ PB dengan motede ASPEN walaupun hubunganya tidak begitu erat.(Tabel 1). Sebanyak 15 (78,9\%) dari 19 anak yang memiliki risiko malnutrisi tersebut dapat terjaring dengan penilaian orang tua menurut metode ASPEN (Tabel 4), Kemampuan test untuk menunjukkan individu yang berisiko, benar benar berisiko adalah sebesar 78,95\% ( sensitivitas), Kemampuan test untuk menunjukkan individu yang tidak berisiko, benar benar tidak berisiko adalah sebesar $28,57 \%$ (spesifisitas), proporsi anak yang tes nya berisiko dan betul berisiko. Dengan kata lain "Jika tes seseorang positif berisiko, berapa probabilitas dia betulbetul berisiko?" dari table didapat $27,27 \%$ nilai prediksi bahwa seorang positif beriko dan bernar-benar berisiko (NPP), dan proporsi pasien yang tes nya normal dan betulbetul tidak berisiko. Bisa juga dikatakan "Jika tes seseorang negative (normal), berapa probabilitas dia betul-betul tidak berisiko?" dari table didapat $80 \%$ nilai prediksi negative artinya mampu meprediksi seseorang tidak berisiko(NPN). Dengan (+) LR mempunyai nilai yang lebih besar 1,1053 dibandingkan (-)LR. artinya meskipun NPN lebih besar disbanding NPP akan tetapi perbandingan Rasio (+)LR lebih besar dibandingkan (-)LR. (tabel 5)

Uji statistik tersebut menunjukkan bahwa metode ASPEN memiliki sensitivitas yang cukup tinggi dalam menjaring risiko malnutrisi oleh orang tua walaupun memiliki spesifisitas yang rendah sehingga memungkinkan overdiagnosis. ${ }^{20}$ Namun, metode ini dapat diterima atas dasar pemikiran:

- Untuk menjaring anak yang mengalami masalah kesehatan serius dan memiliki angka kejadian yang tinggi di masyarakat sehingga diperlukan metode yang mempunyai sensiitivitas tinggi, walaupun spesifisitasnya rendah. ${ }^{21}$

- Metode ASPEN merupakan uji saring risiko malnutrisi oleh orang tua dengan diagnosis akhir ditentukan oleh dokter yang akan memberikan tindakan tertentu bila terdiagnosis sebagai anak dengan risiko malnutrisi.
- Penerapan uji saring risiko atau deteksi dini status nutrisi oleh orang tua merupakan salah satu bentuk edukasi penanggulangan masalah nutrisi dimasyarakat.

- Sangat sulit memiliki uji diagnostik terutama yan dilakukan oleh orang tua, yang memiliki sensitivitas dan spesifisitas yang tinggi.

\section{Simpulan}

Penilaian statistik risiko malnutrisi anak oleh orang tua menurut metode ASPEN memiliki sensitivitas yang baik walaupun memiliki spesifisitas yang rendah. Untuk menjaring anak yang mengalami masalah kesehatan penting dan banyak terjadi di masarakat diperlukan metode uji diagnostik dengan sensitifitas yang cukup tinggi walaupun dengan spesifisitas yang rendah. Diagnosis akhir dilakukan oleh dokter dengan mepergunakan metode yang lebih akurat. Dengan demikian, metode ASPEN dapat dipakai oleh orang tua untuk melaksanakan deteksi dini anak dengan risiko mengalami malnutrisi.

\section{Daftar pustaka}

1. Badan Penelitian dan Pengembangan Kesehatan. Riset kesehatan dasar. Jakarta; Kementrian Kesehatan RI; 2013.

2. Rub G, Marderfeld L, Poraz, dkk. Validation of a nutritional screening tool for ambulatory use in pediatrics. J Pediatr Gastroenterol Nutr. 2016;62:771-5.

3. Schuitema CJ, Klos M, Kouwenoord K, Kruizenga H, Meester WR. Guideline screening and treatment of malnutrition; Amsterdam: fight malnutrion; 2011.

4. Seal A, Kerac M. Operational implications of using 2006 World Health Organization growth standards in nutrition programmes: secondary data analysis. Br Med J 2007:1-6.

5. World Health Organization. Use of world health organization and CDC growth charts for children aged 0-59 months in the United States: Jeneva; WHO; 2010.

6. Koletzko B. Pediatric nutrition in practice. Edisi kedua. Jerman : World Review of Nutrition and Dietetics 2015;113:6-13.

7. Mehta NM, Corkins MR, Lyman BL, dkk. Defining pediatric malnutrition: A paradigm shift toward etiology-related definitions. J Parenter Enteral Nutr 2013;37:460-81.

8. Tanumihardjo SA, Andherson C, Horwitz MK, dkk. Poverty, Obesity, and Malnutrition: An International Perspective Recognizing the paradox. J Am Diet Assoc 2007;107:1966-72. 
9. Joosten K, Meyer R. Nutritional screening and guidlines for managing the child with faltering growth. Eur J Clin Nutr 2010;64:S22-4.

10. Kondrup J, Allison SP, Elia M, Vellas B, Plauth M. ESPEN guidlines for niutrition screening. Clin Nutr 2003;22:415-21.

11. Simpsom R, Keller HH, Rysdale LA, Beyers JE. Nutrition screening tool for every preschooler (NutriSTEP): Validation and tst-retest reliabilty of a parent-administered quetionnaire assesing nutrition risk of preschoolers. Eur J Clin Nutr 2008;62:770-80.

12. Malnutrition Awarness week. Ask about your child's nutrition. J Parenter Enteral Nutr; 2016.

13. Pathak R, Sharma RC, Parvan UC, Gupta, Ojha RK, Goel NK. Behavioural and emotional problems in school going adolescents. Australas Med J 2011;4:15-21.

14. Roberfroid D, Hammami N, Lachat C, dkk. Utilization of mid-upper arm circumfrence versus weight for geight in nutritional rehabilitation programmes: a systematic review of evidence. Geneva: WHO; 2013.
15. Cederholom T, Bpsaeus I, Barazzoni R, dkk. Diagnostic criteria for malnutrition - An ESPEN consenseus statment. J Clin Nutr 2015:335-40.

16. Maqbool A, Olsen IE, Stalling VA. Clinical assessment of nutritional status. Nutr Pediatr 2008:5-13.

17. Donini LM, Lenzi A, Neni B, Marchesini G. Risk of malnutrition (over and undernutrition): Validation of the JaNuS screening tool. J Clini Nutr 2013;12.

18. World Health Organization. WHO child growth standar. Interpreting growth indicator. Jenewa: WHO; 2008.

19. Becker P CL, Corkins MR, dkk. Consensus statement of the academy of nutrition and dietetics/American society for parenteral and enteral nutrition: Indicators recommended for the identification and documentation of pediatric malnutrition (Undernutrition). J Parenter Enteral Nutr 2015;30:147-61.

20. Wonoputri N, Djais JTB, Rosalina I. Validity of nutritional screening tools for hospitalized children. Nutr Metab J 2014:1-7.

21. Harris M, Taylor G, penyunting. Medical statistic made easy. Edisi ke-3. Bloxham: Scion publishing ltd; 2014. 